\title{
Characterization of the DGAT1 Gene in the New Zealand Dairy Population
}

\author{
R. J. Spelman, ${ }^{*}$ C. A. Ford,† P. McElhinney,† G. C. Gregory, $†$ and R. G. Snell† \\ *Livestock Improvement Corporation, Private Bag 3016, Hamilton, New Zealand \\ †ViaLactia BioSciences Ltd., P.O. Box 109-185, Auckland, New Zealand
}

\begin{abstract}
Recently, DGAT1 was identified as the gene that underlies the QTL for bovine milk production on chromosome 14. This study investigated the effect of the reported polymorphism in three dairy breeds in New Zealand. Statistically significant results were identified for milk fat, milk protein, and volume for Jersey and Holstein-Friesian breeds, and only milk volume for Ayrshires. The average allele substitution effects were 2 to $3 \mathrm{~kg}$ of protein and 120 to $130 \mathrm{l}$ milk for both the Jersey and Holstein-Friesian breeds. For milk fat, the average allele substitution effect was $6 \mathrm{~kg}$ for HolsteinFriesians and $3 \mathrm{~kg}$ for Jerseys. In all breeds, where the polymorphism increased milk fat yield, it decreased milk protein yield and milk volume.
\end{abstract}

(Key words: DGAT1, dairy cattle, quantitative trait loci)

Abbreviation key: DGAT1 = acylCoA:diacylglycerol acyltransferase, DYD = daughter yield deviation, K2332A = lysine to alanine amino acid substitution, QTL = quantitative trait loci.

\section{INTRODUCTION}

Many studies in dairy cattle have shown that a quantitative trait loci (QTL) with major influence on milk production is located in the centromeric end of chromosome 14 (Coppieters et al., 1998; Heyen et al., 1999; Boichard et al., 2000; Looft et al., 2001). This QTL had been fine-mapped to a 3-cM region (Riquet et al., 1999; Farnir et al., 2002), and, more recently, the postulated causative mutation, explaining all of the QTL variation, was reported (Grisart et al., 2002). Grisart et al. (2002) reported on a nonconservative K232A substitution (lysine to alanine amino acid change) in the acylCoA:diacylglycerol acyltransferase (DGAT1) gene and showed that it had a significant effect on milk production traits

Received May 1, 2002.

Accepted June 7, 2002

Corresponding author: R. Spelman; e-mail: rspelman@lic.co.nz. in the New Zealand and Netherlands HolsteinFriesian populations.

This paper outlines and describes the allele frequency and the effect of the DGAT1 polymorphism in the New Zealand population for the Holstein-Friesian, Jersey, and Ayrshire cattle breeds. The economic impact of the polymorphism is also discussed. This is a different and larger dataset than that presented by Grisart et al. (2002) and is the first time the polymorphism has been described in dairy breeds other than Holstein-Friesian.

\section{MATERIALS AND METHODS}

\section{Experimental Structure}

Livestock Improvement Corporation progeny test some 200 to 300 bulls per year. This entails the bulls being genetically evaluated on the basis of 50 to 85 daughters per sire. The sires are evaluated for milk fat, milk protein, milk volume, and 20 nonproduction traits. Semen has been retained from all progeny-tested sires since the early 1970s. DNA was extracted from the semen and genotyped for the DGAT1 polymorphism. The dataset consisted of 113 Ayrshires, 1527 HolsteinFriesians, and 1053 Jersey bulls.

\section{Genotyping}

The $A p A$ (Adenine p Adenine) to $G p C$ (Guanine $\mathrm{p}$ Cytosine) dinucleotide substitution in exon VIII (which causes a lysine to alanine amino acid substitution) of DGAT1 was analyzed using the ABI Prism 7900HT Sequence Detection System (Applied Biosystems, Foster City, CA). Fluorescently labeled probes were designed that would bind to either of the two alleles. Polymerase chain reactions were carried out to amplify a 240-bp fragment to which the probes would bind specifically and fluoresce at a given wavelength. Detection of the different wavelength fluorescence determined the genotype of each animal.

\section{Statistical Analysis}

Consistent with Grisart et al. (2002), this paper will denote lysine as the " $Q$ " allele and the alanine residue 
Table 1. Allele and genotype frequency of the K232A DGAT1 polymorphism by breed $(\mathrm{q}=$ alanine residue and $\mathrm{Q}=$ lysine residue).

\begin{tabular}{llcc}
\hline $\begin{array}{l}\text { Genotype } \\
\text { frequency }\end{array}$ & $\begin{array}{l}\text { Holstein } \\
\text { Friesian }\end{array}$ & Jersey & Ayrshire \\
\hline $\mathrm{qq}$ & 278 & 25 & 66 \\
$\mathrm{Qq}$ & 666 & 194 & 45 \\
$\mathrm{QQ}$ & 583 & 834 & 2 \\
Allele frequency & & & \\
q & 0.40 & 0.12 & 0.78 \\
Q & 0.60 & 0.88 & 0.22 \\
\hline
\end{tabular}

as the "q" allele. Statistical analysis was undertaken using restricted maximum likelihood and the average information algorithm (Johnson and Thompson, 1995). The linear model included the fixed effects of DGAT1 (three classes; 0,1 , and 2 copies of the $\mathrm{Q}$ allele) and a covariate corresponding to the proportion of genetics originating from countries other than New Zealand (overseas genetics). The random effect was animal, with a relationship matrix based on all known relationships. Daughter yield deviations (DYD), weighted averages of a sire's daughter's lactation performances expressed as deviations from the population mean (VanRaden and Wiggans, 1991) were used as the phenotypic measurement. The phenotypes were weighted by a factor based on the variance of the DYD for a son being:

$$
\operatorname{Var} \mathrm{DYD}=\left[\frac{1+(n-1) \frac{1}{4} h^{2}}{n}\right] \sigma_{p}^{2}
$$

where Var DYD is the variance of son's DYD; $n$ is the number of daughters contributing to the DYD; $h^{2}$ is the heritability, which was assumed to be 0.35 for yield traits.

\section{RESULTS}

\section{Allele Frequencies}

The allele frequency is quite different between the three breeds (Table 1). The allele frequency in the Hol-

Table 2. Allele frequency of the K232A DGAT1 polymorphism for the Holstein-Friesian breed for each decile of overseas genetics (osg) ( $\mathrm{q}=$ alanine residue and $\mathrm{Q}=$ lysine residue $)$.

\begin{tabular}{lll}
\hline Percent osg & q allele & Q allele \\
\hline 0 to 10 & 0.29 & 0.71 \\
11 to 20 & 0.28 & 0.72 \\
21 to 30 & 0.37 & 0.63 \\
31 to 40 & 0.40 & 0.60 \\
41 to 50 & 0.33 & 0.67 \\
51 to 60 & 0.36 & 0.64 \\
61 to 70 & 0.44 & 0.56 \\
71 to 80 & 0.40 & 0.60 \\
81 to 90 & 0.62 & 0.38 \\
91 to 100 & 0.76 & 0.24 \\
\hline
\end{tabular}

stein-Friesian breed is influenced greatly by the origin of the genetic material (Table 2). With a greater percentage of overseas genes (predominantly US, Canadian, and Dutch), the frequency of the q allele increases. Thus, the allele frequency in the "pure New Zealand" Holstein-Friesian is similar to that of the Jersey breed. Within the Jersey population, there is no effect of percent overseas genetics on the allele frequency.

\section{Average Allele Substitution Effects}

The average allele substitution effects (Falconer and MacKay, 1996) are consistent in direction between the three breeds, but do differ in absolute value and also statistical significance (Tables 3 to 5 ).

Fat yield. The most statistically significant (lower probability of the null hypothesis) result is for fat yield in the Holstein-Friesian breed. The average allele substitution effect is $5.76-\mathrm{kg}$. In the Jersey breed, the average allele substitution effect is $3.30-\mathrm{kg}$. There is a $7-\mathrm{kg}$ difference between the qq and Qq genotypes and a 3-kg difference between the Qq and QQ genotypes. However, only 25 animals ( $2 \%$ of the dataset) have the qq genotype and, thus, the more reliable contrast for the Jersey cattle is between the heterozygote and QQ homozygotes. The standard error of this contrast (fat yield in Jersey) is $1.08-\mathrm{kg}$ and, thus, significant at the $1 \%$ level. In the Ayrshire population, the average allele substitution effect is of the same magnitude of that for Jerseys, but is not statistically significant.

Protein yield. The average allele substitution effect of the polymorphism for protein yield is $-2.45 \mathrm{~kg}$ for the Holstein-Friesian breed. The average allele substitution effect in the Jersey population is very similar $(-2.48 \mathrm{~kg})$ to that of the Holstein-Friesians. In the Jersey population, the average protein DYD for the heterozygote genotype is greater than that of both of the homozygote classes. This again is due to the low number of animals in the qq class and, therefore, the poor estimate of protein DYD for that genotypic class. In the Ayrshire breed, the allelic effect is very similar to the other two

Table 3. Effect of the K232A DGAT1 polymorphism on fat yield, protein yield, and milk volume in the Holstein-Friesian bull population ( $\mathrm{q}=$ alanine residue and $\mathrm{Q}=$ lysine residue).

\begin{tabular}{lccr}
\hline Item & Fat & Protein & Milk \\
\hline$\alpha$ & 5.76 & -2.45 & -134 \\
qq & 0 & 0 & 0 \\
Qq & 6.86 & -2.13 & -128 \\
QQ & 11.83 & -4.80 & -266 \\
SE $^{1}$ & 0.87 & 0.68 & 24 \\
\hline
\end{tabular}

${ }^{1} \mathrm{SE}=$ average standard error between qq and the two other genotype classes.

$\alpha=$ average allele substitution effect. 
Table 4. Effect of the K232A DGAT1 polymorphism on fat yield, protein yield, and milk volume in the Jersey bull population $(\mathrm{q}=$ alanine residue and $\mathrm{Q}=$ lysine residue). ${ }^{1}$

\begin{tabular}{llcr}
\hline Item & Fat & Protein & Milk \\
\hline$\alpha$ & 3.30 & -2.48 & -110 \\
qq & 0 & 0 & 0 \\
Qq & 7.08 & 1.18 & -31 \\
QQ & 9.87 & -1.80 & -152 \\
SE & 2.46 & 1.71 & 53 \\
SE $^{1}$ & 1.08 & 0.71 & 22 \\
\hline
\end{tabular}

$\mathrm{SE}=$ average standard error between $q \mathrm{q}$ and the two other genotype classes.

$\mathrm{SE}^{1}=$ standard error between $\mathrm{Qq}$ and the $\mathrm{QQ}$ genotype class $\alpha=$ average allele substitution effect.

breeds, but is not statistically significant at the $5 \%$ nominal level.

Milk yield. The size of the average allele substitution effect is similar for the Jersey and Holstein-Friesian breeds ( -110 and $-130 l$, respectively). The standard error for the Jersey breed is $22 l$ for the Qq and $Q Q$ contrast, and thus, the level of statistical significance is the similar for the two breeds. In the Ayrshire population, the average allele substitution effect is larger at $202 l$ and is also significant at the 0.005 nominal level.

Traits other than production. Eighteen traits other than production [17 as described in Spelman et al. (1999) plus longevity] were also analyzed for the DGAT1 polymorphism. In all cases, there was no significant effect of the polymorphism on these traits.

\section{DISCUSSION}

The estimated average allele substitution effects in this study for the Holstein-Friesian breed are comparable to the effects presented by Grisart et al. (2002) for a different New Zealand dataset. The effects for the Dutch animals (Grisart et al., 2002) are larger than the New Zealand effects in absolute values, but are comparable on a genetic standard deviation basis for the two countries. Estimates of additive and dominance effects cannot be made on the presented dataset, as the phenotypes used are DYD (deregressed breeding values). Breeding values are the sum of the average

Table 5. Effect of the K232A DGAT1 polymorphism on fat yield, protein yield, and milk volume in the Ayrshire bull population $(\mathrm{q}=$ alanine residue and $\mathrm{Q}=$ lysine residue).

\begin{tabular}{llcr}
\hline Item & Fat & Protein & Milk \\
\hline qq & 0 & 0 & 0 \\
Qq & 2.79 & -2.61 & -202 \\
QQ & $\cdots$ & $\cdots$ & $\cdots$ \\
SE $^{1}$ & 1.91 & 1.48 & 59 \\
\hline
\end{tabular}

${ }^{1} \mathrm{SE}=$ standard error between $\mathrm{qq}$ and the $\mathrm{Qq}$ genotype class. effects of the genes, and thus, the breeding value (for a specific locus) of the heterozygote is equal to the average of the two homozygotes (Falconer and MacKay, 1996). Additive and dominance effects can be estimated from genotyped cows with lactation yields as the phenotype.

The effects in the three breeds are consistent with respect to their direction, i.e., fat yield is increased with an additional $\mathrm{Q}$, and protein yield and milk volume are reduced. The size of the effects are consistent for protein and milk volume in the Holstein-Friesian and Jersey breeds, but the size of the fat response is nearly double for Holstein-Friesians. The difference in fat effect may be due to the interactions with background genes in the two breeds. Recently, Cases et al. (2001) identified another mammalian DGAT gene (DGAT2) and, thus, it can be postulated that DGAT1 is not acting alone in its role in the formation of triglycerides. However, deletion of both DGAT1 alleles in mice prevents lactation, suggesting a more significant role for DGAT1 in milk production (Smith et al., 2000).

The different allele frequencies between New Zealand and overseas Holstein-Friesians (primarily of US origin) are consistent with the selection objectives in the two countries. The United States have "generally" been selecting for milk volume and recently protein and, thus, the $q$ allele has a selective advantage. This is confirmed in Table 2 with the higher q allele frequencies for the animals with a higher proportion of overseas genetics. The New Zealand population has been traditionally selected for fat. Therefore, the Q allele has had a selective advantage in this population until recently (mid 1980s to 1990s) when protein was added to the selection objective and index.

To test that the observed average allele substitution effect is not a spurious association caused by admixture of two populations with substantially different allele frequencies, we subdivided the Holstein-Friesian dataset into animals that are at least $75 \%$ New Zealand genetics and animals that have less than 25\% New Zealand genetics, and were analyzed separately. The average allele substitution effects for these subgoups were consistent, and thus, confirm that the observed association is not due to recent admixture.

The current relative economic values (NZ\$ per $\mathrm{kg}$ ) for the NZ dairy population economic index are: fat, 1.226; protein, 5.968; and milk, -0.074 . The average allele substitution effect on the economic index is $\$ 2.35$ per additional Q allele for the Holstein-Friesian breed and $-\$ 2.61$ per additional Q allele for the Jersey breed. These effects are approximately 0.1 SD of the economic index. Thus, the selection decision for which allele may differ between the two breeds, with the $\mathrm{Q}$ allele being the desired allele in the Holstein-Friesian breed and 
the $q$ allele being the preferred allele in the Jersey breed. It is likely in the future that different selection objectives will be possibly pursued for different processing and product outcomes. The use of the DGAT1 polymorphism may assist in these breeding choices.

\section{REFERENCES}

Boichard, D. C., F. Grohs, F. Bourgois, F. Cerequeria, R. Faugeras, A. Neau, R. Rupp, Y. Amiques, M. Y. Boscher, and H. Leveziel. 2000. Detection of genes influencing economic traits in three French cattle breeds. Abstract 51st EAAP Mtg., The Hague, The Netherlands.

Cases, S., S. J. Stone, P. Zhou, E. Yen, B. Tow, K. D. Lardizabal, T. Voelker, R. V. Farese, Jr. 2001. Cloning of DGAT2, a second mammalian diacylglycerol acyltransferase, and related family members. J. Biol. Chem. 19:276(42):38870-38876.

Coppieters, W., J. Riquet, J-J. Arranz, P. Berzi, N. Cambisano, B. Grisart, L. Karim, F. Marcq, L. Moreau, C. Nezer, P. Simon, P. Vanmanshoven, D. Wagenaar, and M. Georges. 1998. A QTL with major effect on milk yield and composition maps to bovine chromosome 14. Mamm. Genome 9:540-544.

Falconer, D. S., and T. F. C. Mackay. 1996. Introduction to Quantitative Genetics. 4th ed. Longman Scientific and Technical, New York.

Farnir, F., B. Grisart, W. Coppieters, J. Riquet, P. Berzi, N. Cambisano, L. Karim, M. Mni, P. Simon, D. Wagenaar, J. Vilkki, and M. Georges. 2002. Simultaneous mining of linkage and LD to finemap QTL in outbred half-sib pedigrees: Revisiting the location of a QTL with major effect on milk production on bovine chromosome 14. Genetics: (In press)
Grisart, B., W. Coppieters, F. Farnir, L. Karim, C. Ford, N. Cambisano, M. Mni, S. Reid, R. Spelman, M. Georges, and R. Snell. 2002. Positional candidate cloning of a QTL in dairy cattle:identification of a missense mutation in the bovine DGAT1 gene with major effect on milk yield and composition. Genome Research 12:222-231.

Heyen, D. W., J. I. Weller, M. Ron, M. Band, J. E. Beever, E. Feldmesser, Y. Da, G. R. Wiggans, P. M. VanRaden, and H. A. Lewin. 1999. A genome scan for QTL influencing milk production and health traits in dairy cattle. Physiol. Genomics 1:165-175.

Johnson, D. L., and R. Thompson. 1995. Restricted maximum likelihood estimation of variance components for univariate animal models using sparse matrix techniques and average information. J. Dairy Sci. 78:449-456.

Looft, C., N. Reinsch, C. Karall-Albrecht, S. Paul, M. Brink, H. Thomsen, G. Brockmann, C. Kuhn, M. Schwerin, and E. Kalm. 2001. A mammary gland EST showing linkage disequilibrium to a milk production QTL on bovine Chromosome 14. Mamm. Genome. 12:646-650.

Riquet, J., W. Coppieters, N. Cambisano, J.-J. Arranz, P. Berzi, S. K. Davis, B. Grisart, F. Farmir, L. Karim, M. Mni, P. Simon, J. F. Taylor, P. Vanmanshoven, D. Wagenaar, J. E. Womack, and M. Georges. 1999. Identity-by-descent fine-mapping of QTL in outbred populations: Application to milk production in dairy cattle. Proc. Natl. Acad. Sci. 96:9252-9257.

Smith, S. J., S. Case, D. R. Jensen, H. C. Chen, E. Sande, B. Tow, D. A. Sanan, J. Raber, R. H. Eckel, and R. V. Farese, Jr. 2000. Obesity resistance and multiple mechanisms of triglyceride synthesis in mice lacking Dgat. Nature Genetics. 25(1):87-90.

Spelman, R. J., A. E. Huisman, S. R. Singireddy, W. Coppieters, J. Arranz, M. Georges, and D. J. Garrick. 1999. Short Communication: Quantitative Trait Loci Analysis on 17 Nonproduction Traits in the New Zealand Dairy Population. J. Dairy Sci. 82:2514-2516.

VanRaden, P. M., and G. R. Wiggans. 1991. Derivation, calculation, and use of National Animal Model Information. J. Dairy Sci. 74:2737-2746. 